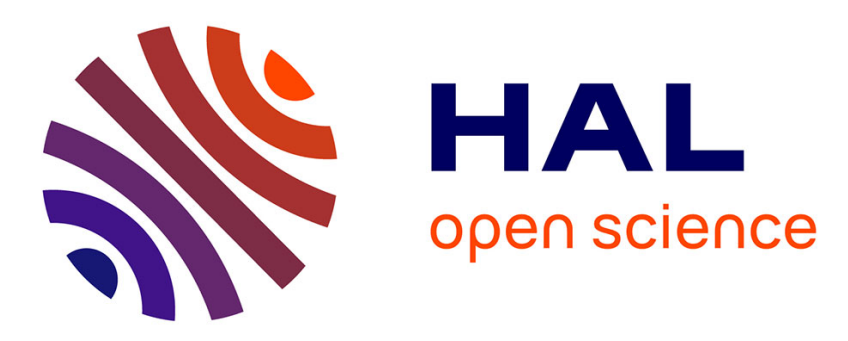

\title{
Two cases of opportunistic parasite infections in patients receiving alemtuzumab
}

\author{
Guillaume Desoubeaux, Charline Caumont, Christophe Passot, Caroline \\ Dartigeas, Éric Bailly, Jacques Chandenier, Thanh Haï Duong
}

\section{To cite this version:}

Guillaume Desoubeaux, Charline Caumont, Christophe Passot, Caroline Dartigeas, Éric Bailly, et al.. Two cases of opportunistic parasite infections in patients receiving alemtuzumab. Journal of Clinical Pathology, 2011, 65 (1), pp.92-95. 10.1136/jclinpath-2011-200403 . hal-02439688

\section{HAL Id: hal-02439688 \\ https://hal.science/hal-02439688}

Submitted on 14 Jan 2020

HAL is a multi-disciplinary open access archive for the deposit and dissemination of scientific research documents, whether they are published or not. The documents may come from teaching and research institutions in France or abroad, or from public or private research centers.
L'archive ouverte pluridisciplinaire HAL, est destinée au dépôt et à la diffusion de documents scientifiques de niveau recherche, publiés ou non, émanant des établissements d'enseignement et de recherche français ou étrangers, des laboratoires publics ou privés. 
archives-ouvertes

\title{
Two cases of opportunistic parasite infections in patients receiving alemtuzumab
}

\author{
Guillaume Desoubeaux, Charline Caumont, Christophe Passot, Caroline \\ Dartigeas, Éric Bailly, Jacques Chandenier, Thanh Duong
}

\section{To cite this version:}

Guillaume Desoubeaux, Charline Caumont, Christophe Passot, Caroline Dartigeas, Éric Bailly, et al.. Two cases of opportunistic parasite infections in patients receiving alemtuzumab. Journal of Clinical Pathology, BMJ Publishing Group, 2011, 10.1136/jclinpath-2011-200403 . hal-02439688

\section{HAL Id: hal-02439688 \\ https://hal.archives-ouvertes.fr/hal-02439688}

Submitted on 14 Jan 2020

HAL is a multi-disciplinary open access archive for the deposit and dissemination of scientific research documents, whether they are published or not. The documents may come from teaching and research institutions in France or abroad, or from public or private research centers.
L'archive ouverte pluridisciplinaire HAL, est destinée au dépôt et à la diffusion de documents scientifiques de niveau recherche, publiés ou non, émanant des établissements d'enseignement et de recherche français ou étrangers, des laboratoires publics ou privés. 


\title{
Two cases of opportunistic parasite infections in patients receiving alemtuzumab
}

\author{
Guillaume Desoubeaux, ${ }^{1}$ Charline Caumont, ${ }^{1}$ Christophe Passot, ${ }^{2}$ Caroline Dartigeas, ${ }^{3}$ \\ Éric Bailly, ${ }^{1}$ Jacques Chandenier, ${ }^{1}$ Thanh Haï Duong ${ }^{1}$
}

${ }^{1}$ Unit of Parasitology -

Mycology - Tropical Medicine, CHRU Bretonneau, Tours,

France

${ }^{2}$ Immunology Laboratory, CHRU

Bretonneau, Tours, France

${ }^{3}$ Service of Haematology and

Cellular Therapy, CHRU

Bretonneau, Tours, France

\section{Correspondence to}

Dr Guillaume Desoubeaux, Unit of Parasitology - Mycology Tropical Medicine, University Hospital Bretonneau, 2 Blvd Tonnellé, Bâtiment B2A, 37044 Tours Cedex 09, France: guillaume.desoubeaux@ univ-tours.fr

Accepted 20 September 2011

\section{ABSTRACT}

Two cases are reported of rare digestive opportunistic parasites in patients being treated with alemtuzumab for lymphoid haematological malignancies. In both patients, classical biological examinations were insufficient to reach the diagnosis. Only specific parasitological techniques enabled diagnoses of cryptosporidiosis and microsporidiosis, respectively. In both cases, cellular immune reconstitution was sufficient to eradicate these opportunistic infections. In this context, parasitological diagnosis is often underestimated by medical practitioners, so immunologists and oncohaematologists need to be aware of this kind of opportunistic pathogen.

Numerous digestive complications-infectious or non-infectious - may arise during treatment with alemtuzumab (Campath; Genzyme, USA). ${ }^{1-3}$ Among these, two rare parasites which are wellknown in departments of infectious diseases, particularly during the HIV/AIDS outbreak, may be suspected. Case reports of two patients treated with alemtuzumab in whom opportunistic parasitic infections developed are described.

\section{CASE 1}

A 75-year-old woman was monitored for stage C chronic lymphocytic leukaemia (CLL) initially diagnosed in 2005. She was started on a fourth course of treatment with alemtuzumab at the end of March 2011 and pancytopenia with lymphocyte depletion (measured values $\left.0-0.610 \times 10^{9} / 1\right)$ was noticed on regular complete blood counts. In May 2011 she presented with a 2-week history of diarrhoea with at least three watery stools per day. She had not undertaken any foreign travel. All the routine tests were negative (bacterial culture, virus research by immunological or molecular methods, standard stool analysis for parasites and anatomopathological examinations of bowel biopsies). As the stools were very liquid, the parasitology laboratory decided to perform further investigations. The temporary wet mount and two concentration techniques (Bailenger's sedimentation and Kato-Katz's techniques) were negative, but Ziehl-Neelsen staining revealed the presence of Cryptosporidium oocysts on smears of methanol-fixed faeces (figure 1 ) and $C$ meleagridis was identified upon 18S rRNA gene sequencing. Treatment of symptoms and an increase in lymphocyte count after stopping alemtuzumab treatment resulted in a favourable outcome within a few weeks.

\section{CASE 2}

A 77-year-old man presented with uncontrolled CLL after five sessions of chemotherapy. Alemtuzumab treatment was started in January 2011. Complete blood counts showed lymphocyte counts of $0.3-0.8 \times 10^{9} / 1$ from January to June 2011 . Since starting treatment with alemtuzumab, recurrent aqueous diarrhoea had occurred. The patient had not undertaken any foreign travel. Routine biological tests were negative. The only test with a positive result was Enterocytozoon bieneusi real-time PCR with internal positive control performed on a stool sample (LightCycler 480, Roche Diagnostics, France) (figure 2). The microsporidial gene fragment targeted was the SSU rDNA. Designed Eb1 (5'-CGACAGCCTGTGTGTGAGAATAC) and Eb5 (5'-CAACGAATGACTTGACCCTGGTAA) were used as primers and EbS2 (6FAM TGCTTAATTTAACTCAACGCGGGAAAA TAMRA) was chosen as the fluorescent TaqMan probe. Parasitological confirmation was made with Weber's Trichrome blue stain (figure 3) and van Gool's Uvitex 2B fluorescent brightener (figure 4) which enabled detection of microsporidia. As the lymphocyte count reached the value of $1 \times 10^{9} / 1$, the diarrhoea gradually decreased without specific treatment. Neither a whole microsporidial microorganism nor DNA was detected in later stool samples after total cellular immune reconstitution obtained within 3 months.

\section{DISCUSSION}

Microorganisms of the genuses Enterocytozoon and Cryptosporidium are ubiquitous unicellular

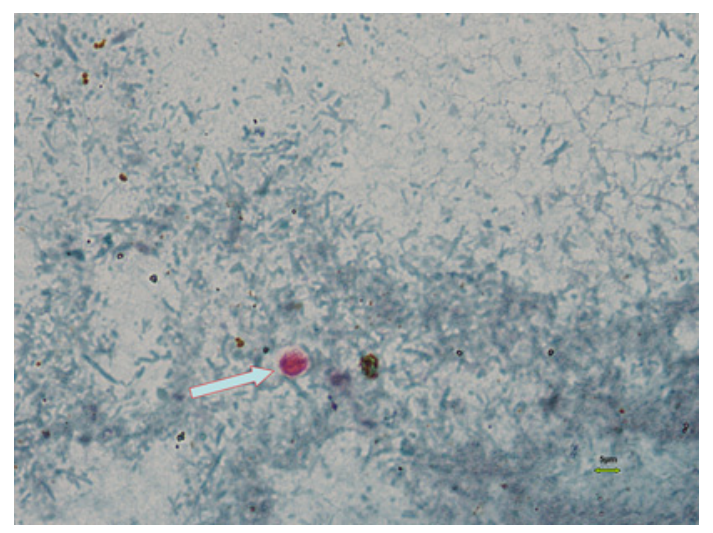

Figure 1 Cryptosporidium oocysts stained with ZiehleNeelsen acid fast stain (x1000 magnification). The arrow shows the oocyst stained sharply on a blue-green background and measuring $5 \mathrm{~m}$. When sporulation occurs, sporozoites are sometimes clearly visible inside the oocyst. 

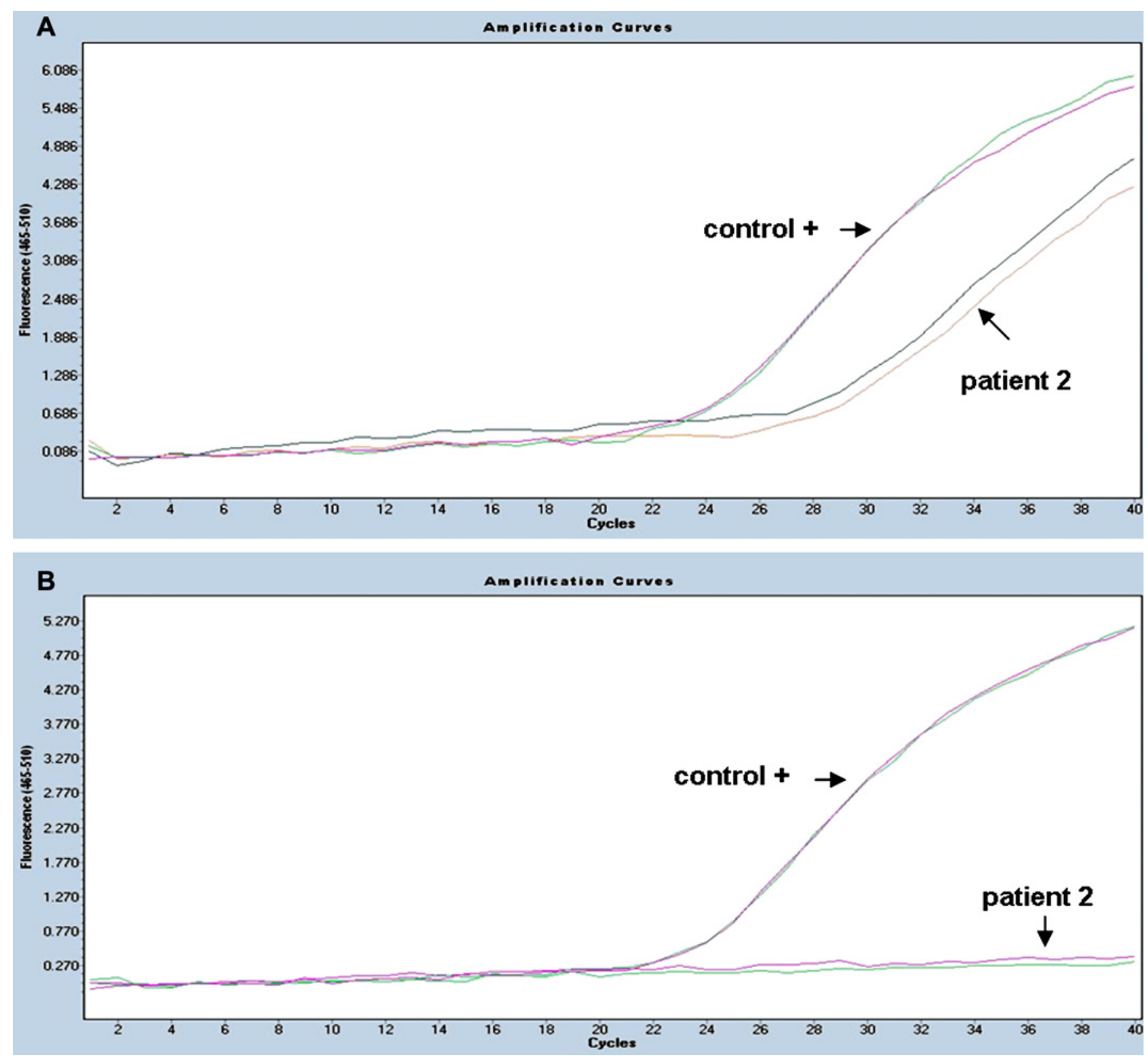

Figure 2 Amplification curves of Enterocytozoon bieneusi TaqMan real-time PCR processes at (A) diagnosis and (B) after immune recovery. Each sample was analysed in duplicate, simultaneously with a positive control. Control DNA was detected with an average $C_{t}$ of 26 cycles. At the time of diagnosis, $C_{t}$ in patient 2 was considered positive at 28 and 30 amplification cycles. As the white blood cell count reached the rate of $1 \times 10^{9} / l$ lymphocytes, no microsporidial DNA was further detected.

eukaryotes whose epidemiology is often linked to the quality of the water source. ${ }^{4}$ The former belongs to the Microsporidia group and the latter are coccidia of the Apicomplexa phylum. Until the middle of the 1990s, microsporidiosis and cryptosporidiosis had been described during episodes of diarrhoea primarily in HIV-positive persons with AIDS. Since the advent of the highly active antiretroviral therapies in 1996, such infections have become rare in treated persons. At present, few cases are diagnosed in non-HIV subjects, particularly those undergoing solid organ transplantation/bone marrow graft or those with leukaemia. $^{6-9}$ Although the number of cases remains small, these opportunistic parasites can be highly pathogenic, especially when the number of CD4 T lymphocytes is $<0.2 \times 10^{9} / 1$ (note also that immunocompetent subjects may be sporadically affected by cryptosporidiosis although the pathogenesis is appreciably different from in immunocompromised patients). As soon as it is suspected, the diagnosis of cryptosporidiosis is easy and almost all laboratories should be able to perform correct staining for Cryptosporidium. In contrast, very few laboratories can provide a reliable microscopic diagnosis of microsporidiosis.

For the last 20 years the use of monoclonal antibodies has provided a significant improvement in the medical management of cancer and autoimmune diseases. Alemtuzumab is a humanised monoclonal antibody derived from rat. This recombinant IgG1 $\mathrm{K}$ targets CD52, a $21-28 \mathrm{kDa}$ surface glycoprotein seen particularly on mature lymphocytic cells. It is thought to work via the activation of antibody-dependent cell-mediated cytotoxicity ${ }^{10}$ and/or complement cytotoxicity. ${ }^{11}$ This drug is indicated in the treatment of relapsing or complicated $\mathrm{CLL}^{12}$ and in some kinds of non-Hodgkin's lymphoma. Alemtuzumab is also 


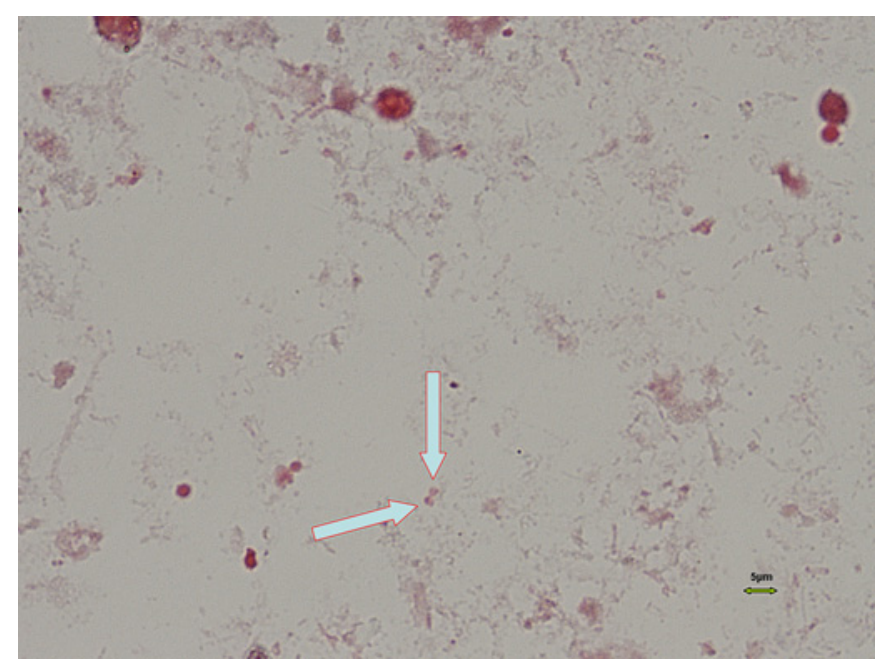

Figure 3 The arrows show two microsporidia spores stained with Weber's Trichrome blue stain (x1000 magnification). The parasitic structures of small size (approximately 1-2 m) are dark in contrast to the pale background. Mature spores contain a clearly visible vacuole.

sometimes used in some conditioning regimens for bone marrow graft ${ }^{13}$ or solid organ transplantation. ${ }^{14}$ It has also recently been investigated in a phase II clinical trial in the treatment of relapsing-remitting multiple sclerosis. ${ }^{15}$ One of the major known potential adverse events of alemtuzumab is the increased risk for onset of opportunistic infections due to intense lymphocyte depletion associated with profound cellular immune dysfunction. ${ }^{16-18}$ No correlation exists between the cumulative dose of alemtuzumab and the length or severity of immunodepletion. Many reactivations with herpes or hepatitis viruses have been reported, especially shortly after the $\mathrm{T}$ cell nadir. For instance, cytomegalovirus reactivation is described in $10-25 \%$ of patients receiving alemtuzumab after about 4-6 weeks of treatment. ${ }^{19} 20$ A few bacterial, ${ }^{2}$ fungal ${ }^{21}$ or even parasitic infections ${ }^{22}$ have also been reported. ${ }^{1323}$ This potential risk therefore requires investigation of the viral serological status

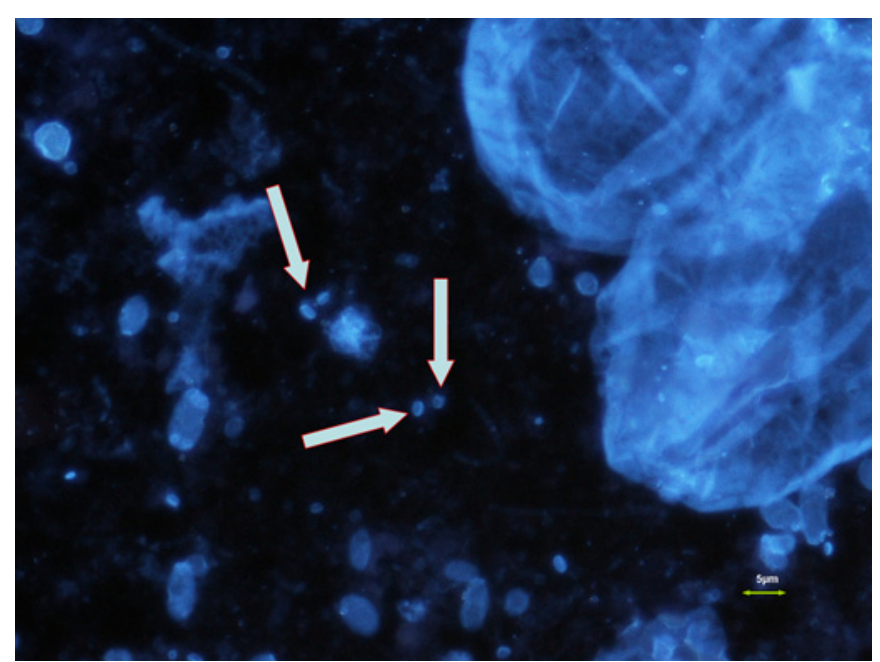

Figure 4 Microsporidia spores stained with Uvitex 2B fluorescence stain ( $\times 1250$ magnification). Once suspected, a confirmatory test is needed to establish the presence of a microsporidial spore. Enterocytozoon bieneusi spores are seen quite easily with a fluorescent brightening agent. This latter product fits in the chitinous cell wall of this kind of microsporidia. Note that the edge of the vacuole appears like a stick inside the parasitic structure.

\section{Take-home message}

During therapies including monoclonal antibodies, opportunistic parasits should be suspected as digestive symptoms have began, especially when they last a few weeks, in spite of antibiotics.

and bacterial colonisation index. In this context, prophylaxis against various infectious agents should be given until immune reconstitution. ${ }^{18} 24-26$

In contrast, infrequent digestive complications due to unicellular pathogens such as microsporidia or cryptosporidia are less well-known and are often misdiagnosed during treatment with alemtuzumab. To our knowledge, very few cases of microsporidiosis have been reported in patients treated with alemtuzumab. ${ }^{27}$ No report has been found of cryptosporidiosis caused by this monoclonal antibody. ${ }^{23}$ In this context, the risk of such rare opportunistic parasites is not well known so it is not sought. However, it appears to be theoretically realistic, even if there has been no travel in tropical countries. Usually, when bowel symptoms are observed, digestive graft-versus-host disease, drug toxicity or bacterial/viral infections are suspected. As in our case reports, a diagnosis of digestive parasitic infections usually involves excluding other illnesses. According to the Crypto-ANOFEL French network recommendations, specific parasitological techniques should be performed in cases of liquid diarrhoea occurring during immunodepletion. For these two patients, the laboratory used Ziehl-Neelsen staining for cryptosporidia and Weber staining for microsporidia detection followed by confirmation with fluorescence. ${ }^{28}$ In our laboratory, molecular methods, which are more sensitive, are recommended for easier screening of small pathogens such as microsporidia E bieneusi and are therefore used automatically first on every liquid stool. This method is now standardised, validated and can also be performed with many real-time machines (Roche (France), Applied Biosystems).

These cases strengthen the need to consider such environmental eukaryotes as potential pathogens in immunocompromised subjects, including unusual patients from oncohaematology treated with monoclonal antibodies such as alemtuzumab. A knowledge of the broad panel of potential infectious agents enables a better approach for clinicians. ${ }^{23}$ A delay in the time to diagnosis can impact on the success of the medical care. A few antiparasitic treatments have been used with interesting but controversial successes (eg, nitazoxanide for cryptosporidia, fumagillin for Enterocytozoon spp. microsporidia). ${ }^{29} 30$

\section{CONCLUSION}

Our findings suggest that patients treated with alemtuzumab must be considered a new group of patients with increased susceptibility to this kind of microorganism, even if they have not travelled abroad. They should be monitored closely, with an emphasis on researching opportunistic infections-including parasitological infections - especially around the fourth week of treatment when the lymphocyte number is lowest.

Acknowledgements The authors thank all the personnel in the Parasitology and Haematology laboratories for their collaboration.

\section{Competing interests None.}

Patient consent Obtained.

Contributors Study concept and design: GD, JC. Acquisition of data: GD, CC, CD, JC Analysis and interpretation of data: GD, CC, ?Duong, JC. Drafting of the manuscript: 
GD, ?Duong, JC. Critical revision of the manuscript for important intellectual content: GD, CC, CP, EB, ?Duong, JC. Administrative, technical or material support: GD, JC. Study supervision: GD, JC. All authors had full access to all of the data in the study and take responsibility for the integrity of the data and the accuracy of the data analysis.

Provenance and peer review Not commissioned; externally peer reviewed.

\section{REFERENCES}

1. Martin SI, Marty FM, Fiumara K, et al. Infectious complications associated with alemtuzumab use for lymphoproliferative disorders. Clin Infect Dis 2006;43:16-24.

2. Nosari A, Tedeschi A, Ricci F, et al. Characteristics and stage of the underlying diseases could determine the risk of opportunistic infections in patients receiving alemtuzumab. Haematologica 2008;93:e30-1.

3. Peleg AY, Husain S, Kwak EJ, et al. Opportunistic infections in 547 organ transplant recipients receiving alemtuzumab, a humanized monoclonal CD-52 antibody. Clin Infect Dis 2007:44:204-12.

4. Didier ES. Microsporidiosis: an emerging and opportunistic infection in humans and animals. Acta Trop 2005;94:61-76.

5. Collinet-Adler S, Ward HD. Cryptosporidiosis: environmental, therapeutic, and preventive challenges. Eur J Clin Microbiol Infect Dis 2010;29:927-35.

6. Kelkar R, Sastry PS, Kulkarni SS, et al. Pulmonary microsporidial infection in a patient with CML undergoing allogeneic marrow transplant. Bone Marrow Transplant 1997;19:179-82.

7. Orenstein JM, Russo P, Didier ES, et al. Fatal pulmonary microsporidiosis due to encephalitozoon cuniculi following allogeneic bone marrow transplantation for acute myelogenous leukemia. Ultrastruct Pathol 2005;29:269-76.

8. Yazar S, Eser B, Yalçin $\mathrm{S}$, et al. A case of pulmonary microsporidiasis in an acute myeloblastic leukemia (AML) - M3 patient. Yonsei Med J 2003;44:146-9.

9. Yoken J, Forbes B, Maguire AM, et al. Microsporidial endophthalmitis in a patient with acute myelogenous leukemia. Retina 2002;22:123-5.

10. Ferrajoli A, O'Brien S, Keating MJ. Alemtuzumab: a novel monoclonal antibody. Expert Opin Biol Ther 2001;1:1059-65.

11. Bologna $\mathbf{L}$, Gotti $E$, Manganini $M$, et al. Mechanism of action of type II, glycoengineered, anti-CD20 monoclonal antibody GA101 in B-chronic lymphocytic leukemia whole blood assays in comparison with rituximab and alemtuzumab. J Immunol 2011;186:3762-9.

12. Jaglowski SM, Alinari L, Lapalombella $\mathrm{R}$, et al. The clinical application of monoclonal antibodies in chronic lymphocytic leukemia. Blood 2010;116:3705-14

13. Poiré $\mathbf{X}$, van Besien K. Alemtuzumab in allogeneic hematopoetic stem cell transplantation. Expert Opin Biol Ther 2011;11:1099-111.

14. Safdar N, Smith J, Knasinski V, et al. Infections after the use of alemtuzumab in solid organ transplant recipients: a comparative study. Diagn Microbiol Infect Dis 2010;66:7-15.
15. Fox EJ. Alemtuzumab in the treatment of relapsing-remitting multiple sclerosis. Expert Rev Neurother 2010;10:1789-97.

16. Keating MJ, Flinn I, Jain V, et al. Therapeutic role of alemtuzumab (Campath-1H) in patients who have failed fludarabine: results of a large international study. Blood 2002;99:3554-61.

17. Rigal E, Gateault $P$, Lebranchu $Y$, et al. [Therapeutic monoclonal antibodies: update on the risk of opportunistic infections] (In French). Med Sci (Paris) 2009;25:1135-40.

18. Thursky KA, Worth LJ, Seymour JF, et al. Spectrum of infection, risk and recommendations for prophylaxis and screening among patients with lymphoproliferative disorders treated with alemtuzumab*. Br J Haematol 2006;132:3-12.

19. Morrison VA. Infectious complications in patients with chronic lymphocytic leukemia: pathogenesis, spectrum of infection, and approaches to prophylaxis. Clin Lymphoma Myeloma 2009;9:365-70.

20. Nguyen DD, Cao TM, Dugan K, et al. Cytomegalovirus viremia during Campath-1H therapy for relapsed and refractory chronic lymphocytic leukemia and prolymphocytic leukemia. Clin Lymphoma 2002;3:105-10.

21. Bassetti M, Repetto $E$, Mikulska M, et al. Cryptococcus neoformans fatal sepsis in a chronic lymphocytic leukemia patient treated with alemtuzumab: case report and review of the literature. J Chemother 2009:21:211-14.

22. Pitini V, Cascio A, Arrigo C, et al. Visceral leishmaniasis after alemtuzumab in a patient with chronic lymphocytic leukaemia. Br J Haematol. Published Online First: 25 July 2011. doi:10.1111/.1365-2141.2011.08802.x. http://www.ncbi.nlm.nih.gov/ pubmed/21790529 (accessed 12 Aug 2011)

23. Salvana EM, Salata RA. Infectious complications associated with monoclonal antibodies and related small molecules. Clin Microbiol Rev 2009;22:274-90.

24. Lundin J, Porwit-MacDonald A, Rossmann ED, et al. Cellular immune reconstitution after subcutaneous alemtuzumab (anti-CD52 monoclonal antibody, CAMPATH-1H) treatment as first-line therapy for B-cell chronic lymphocytic leukaemia. Leukemia 2004; 18:484-90

25. O'Brien SM, Kantarjian HM, Thomas DA, et al. Alemtuzumab as treatment for residual disease after chemotherapy in patients with chronic lymphocytic leukemia. Cancer 2003;98:2657-63.

26. Oscier D, Fegan C, Hillmen P, et al; Guidelines Working Group of the UK CLL Forum British Committee for Standards in Haematology. Guidelines on the diagnosis and management of chronic lymphocytic leukaemia. Br J Haematol 2004:125:294-317.

27. Jamet D, Quinio D, Moalic E, et al. [Systemic microsporidiosis and toxoplasmosis in a patient with T prolymphocytic leukemia] (In French). Med Mal Infect 2009:39:406-8.

28. Chioralia G, Trammer $\mathrm{T}$, Kampen $\mathrm{H}$, et al. Relevant criteria for detecting microsporidia in stool specimens. J Clin Microbiol 1998;36:2279-83.

29. Rossignol JF, Ayoub A, Ayers MS. Treatment of diarrhea caused by Cryptosporidium parvum: a prospective randomized, double-blind, placebo-controlled study of nitazoxanide. J Infect Dis 2001;184:103-6.

30. Molina JM, Tourneur M, Sarfati $C$, et al. Fumagillin treatment of intestinal microsporidiosis. N Engl J Med 2002;346:1963-9. 